\title{
A review of Australian mosasaur occurrences
}

\section{B.P. $\operatorname{Kear}^{1,2, *}$, J.A. Long $^{3,4}$ \& J.E. Martin ${ }^{5}$}

1 School of Earth and Environmental Sciences, University of Adelaide, Adelaide, South Australia 5005.

2 South Australian Museum, North Terrace, Adelaide, South Australia 5000.

3 Western Australian Museum, Perth, Western Australia 6000.

4 Museum Victoria, Melbourne, Victoria, Australia 3000 (current address).

5 Museum of Geology, South Dakota School of Mines and Technology, Rapid City, South Dakota 57701, USA.

* Corresponding author. Email: kear.ben@saugov.sa.gov.au

Manuscript received: August 2004; accepted: December 2004

\begin{abstract}
Mosasaurs are rare in Australia with fragmentary specimens known only from the Cenomanian-lower Turonian Molecap Greensand (Perth Basin), Campanian - lower Maastrichtian Korojon Calcarenite (Carnarvon Basin), and upper Maastrichtian Miria Formation (Carnarvon Basin), Western Australia. These units were laid down during a near-continuous marine inundation of the western margin of the Australian landmass (which followed separation from India in the Valanginian and genesis of the Indian Ocean) in the Early-Late Cretaceous. The Australian mosasaur record incorporates evidence of derived mosasaurids (mainly plioplatecarpines); however, as yet no specimen can be conclusively diagnosed to genus or species level. The fragmentary nature of the remains provides little basis for direct palaeobiogeographic comparisons. However, correlation with existing data on associated vertebrates, macroinvertebrates and microfossils suggests that the Western Australian mosasaur fauna might have been transitional in nature (particularly following palaeobiogeographic separation of the northern and southern Indian 0ceans during the midCampanian), potentially sharing elements with both northern Tethyan and austral high-latitude regions.
\end{abstract}

Keywords: Mosasaurs, Late Cretaceous, Australia, palaeobiogeography

\section{Introduction}

Australian Cretaceous marine reptile fossils are plentiful although currently poorly documented. At present, most of the described material (comprising mainly ichthyosaurs, plesiosaurs and chelonioid turtles) is derived from extensive lower Cretaceous epicontinental marine deposits in central and northeastern Australia (see Kear, 2003 for summary). In contrast, Late Cretaceous marine reptiles, particularly mosasaurs, are extremely rare. To date, Australian mosasaur remains have been recovered exclusively from continentalmargin marine units in Western Australia, specifically the Cenomanian - lower Turonian Molecap Greensand (Perth
Basin), Campanian - lower Maastrichtian Korojon Calcarenite (Carnarvon Basin) and upper Maastrichtian Miria Formation (Carnarvon Basin).

Several previous reports have dealt with Australian mosasaurs (e.g., Lundelius \& Warne, 1960; Molnar, 1991; Long, 1998, 1999; Kear, 2003, 2004), although few specimens have been thoroughly described. It is, therefore, the purpose of this article to present an up-to-date summary of the Australian mosasaur record and assess its potential palaeobiogeographic relationships. This is intended to provide a platform for more detailed future studies, including a descriptive analysis of Australian mosasaur specimens currently in preparation by JEM and JAL (see Martin \& Long, 2002). 


\section{Abbreviations and terminology}

Repository abbreviations: UWA, University of Western Australia, Perth; WAM, Western Australian Museum, Perth. Lithostratigraphic nomenclature for Australian mosasaur-bearing deposits follows Playford et al. (1976) and Shafik (1990) for the Perth Basin, and Hocking et al. (1987) for Carnarvon Basin units. Informal systematic terminology for Mosasauridae follows the phylogenetic analyses of Bell (1997) with 'russellosaurine' referring to a clade containing Tylosaurinae + Plioplatecarpini, 'plioplatecarpine' referring to the lineage comprising species of Ectenosaurus, Platecarpus and Plioplatecarpus, and 'mosasaurine' referring to the diverse clade incorporating Clidastes, Globidensini, Mosasaurus and Plotosaurus.

\section{Geological setting}

Previous accounts of regional geology (some including maps) and depositional environments for mosasaur-bearing units in Western Australia have been given by Belford (1958), McWae et al. (1958), Playford et al. (1976), Hocking et al. (1987) and Shafik (1990). The geographic distribution of known localities is given in Fig. 1.

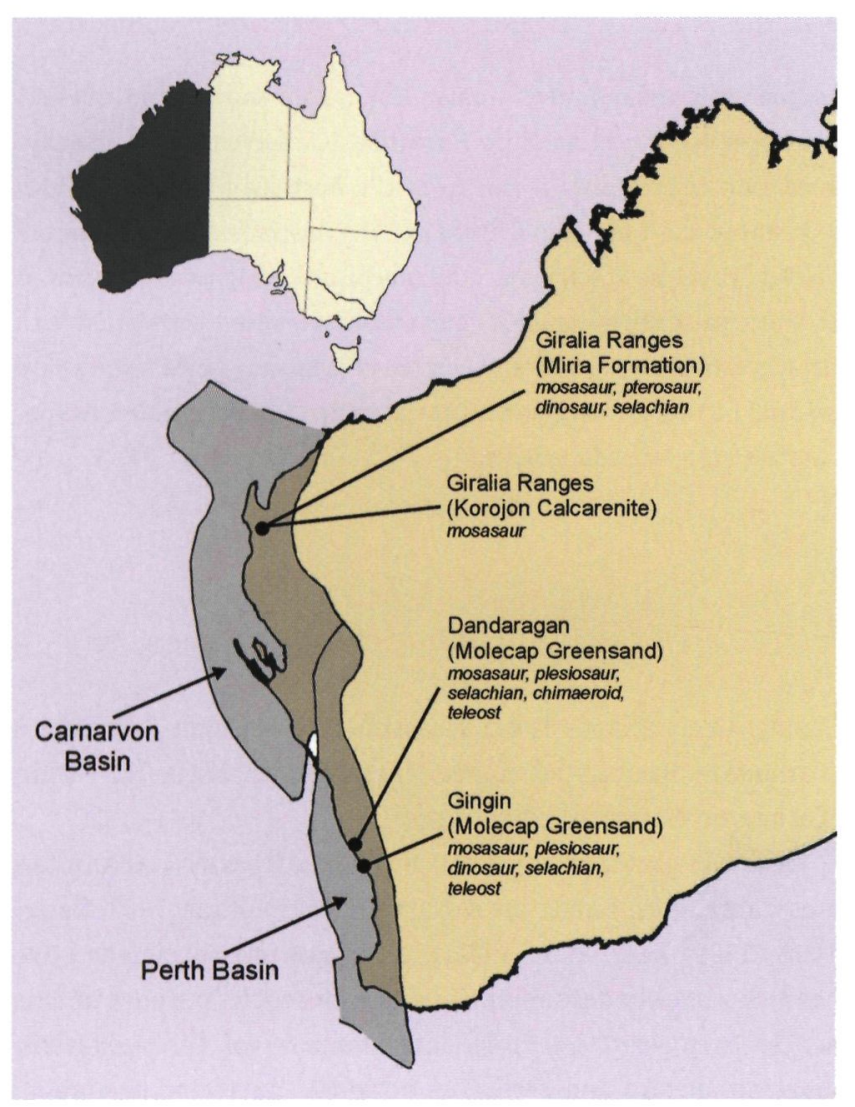

Fig. 1. Map of Western Australia (with Perth and Carnarvon basins shaded) showing localities and units that have produced mosasaur and other associated vertebrate fossils.
At present, Australian mosasaur remains are known solely from the Molecap Greensand, Korojon Calcarenite and Miria Formation. The Molecap Greensand is a continuous sequence of weathered shallow-marine strata that crops out extensively in the southern coastal areas of the Perth Basin in southwestern Western Australia. The unit comprises mainly glauconitic sandstones with a basal phosphatic lag deposit; this may represent either reworked material, or a basal conglomeratic sequence distinct from the overlying sandy sediments. Playford et al. (1976) suggested that the Molecap Greensand was laid down in a transgressive coastal shallow-marine environment, over irregular topography, and with unfavourable, potentially poorly oxygenated bottom-water conditions.

The age of the Molecap Greensand is contentious. Rich palynomorph assemblages have been used to determine a Cenomanian-early Turonian range (Shafik, 1990). This contrasts with some earlier estimates, which favour a much younger late Coniacian-early Santonian age for the deposit (Belford, 1958; McWae et al., 1958). Macrofossils are sporadic throughout the Molecap Greensand but include fragmentary remains of mosasaurs, plesiosaurs, selachians, chimaeroids, teleost fish and dinosaurs. Isolated, probably reworked ichthyosaur material is also known from the basal part of the sequence. Invertebrates are uncommon (an artifact of poor preservation), and only a handful of benthic molluscan taxa have been identified (see Etheridge, 1913; Feldtmann, 1951, 1963; Henderson et al., 2000).

The Korojon Calcarenite together with the overlying Miria Formation comprise a thin sequence of condensed, uncemented chalk (foraminiferal calcarenite) with abundant phosphatic grains and nodules. Both units were laid down under predominantly low-energy, shallow-marine shelf conditions, established during a latest Cretaceous transgressive episode in the Carnarvon Basin of northwestern Western Australia (Apthorpe, 1979; Hocking et al., 1987). A distinct series of winnowed sediments rich in nodular phosphorite forms the uppermost portion of the Korojon Calcarenite and marks the boundary with the Miria Formation. This corresponds to a probable midMaastrichtian regressive event, recognised by a widespread disconformity in strata of that age all along the Western Australian continental margin (McNamara et al., 1988).

Both the Korojon Calcarenite and Miria Formation are typically poorly exposed but can be recognised in outcrop by phosphatic steinkerns, which occur within the weathering residuum (Henderson \& McNamara, 1985a). These are conspicuous in the type sections in the Giralia Ranges (Giralia and Marilla Anticlines), south of Exmouth Gulf.

The Korojon Calcarenite is generally very poor in macrofossils, although has produced calcitic bivalves (mainly Inoceramus, a characteristic taxon serving to distinguish the Korojon Calcarenite from overlying Miria Formation), rare ammonites and an isolated mosasaur vertebra. Henderson \& McNamara (1985a) considered the paucity of cephalopods and other 
aragonitic shells to be a diagenetic phenomenon, non-indicative of fossil content at the time of deposition. Identification of key heteromorph ammonite taxa including Nostoceras, and early species of Eubaculites have been used to establish an early Maastrichtian age for the upper phosphorite-rich portion of the Korojon Calcarenite (Henderson et al., 1992). Underlying sediments within the sequence are considered largely Campanian in age on the basis of foraminiferal evidence (Edgell, 1957).

Late Cretaceous vertebrate fossils from the Miria Formation include both mosasaurs and selachians. Isolated dinosaur and pterosaur bones suggest deposition in close proximity to land. Macroinvertebrate assemblages are extremely rich comprising a diverse range of pelagic cephalopods (Glenister et al., 1956; Henderson \& McNamara, 1985b; Henderson et al., 1992, 2000) and benthic molluscs (Darragh \& Kendrick, 1991, 1994; Henderson et al., 2000). These have been used in conjunction with microfossil data (see Henderson et al., 2000) to indicate temperate to warm temperate sea surface temperatures at the time of deposition (Darragh \& Kendrick, 1994). Species of the planispiral Pachydiscus (Pachydiscus), and distinctive heteromorph ammonite taxa including Baculites, Eubaculites, Glyptoxoceras and Diplomoceras specify a late Maastrichtian age for the unit (Henderson \& McNamara, 1985b; Henderson et al., 1992).

\section{A review of Australian mosasaur discoveries}

Australian mosasaur remains were first documented by Lundelius \& Warne (1960), who described a fragmentary forelimb (UWA 37092) with abraded ulna and phalanx (Fig. 2A - D), from the upper section of the Molecap Greensand (top of McIntyre Gully section) of McIntyre Gully, near the township of Gingin, on the southwestern coast of Western Australia. The poor condition of the material did not permit assignment to a specific taxon, although general morphology of the ulna and slender proportions of the associated phalanx (see Lundelius \& Warne, 1960 for discussion of characters), are sufficient to warrant possible affinity with Platecarpus (Lundelius \& Warne, 1960; Long, 1998). Long $(1990,1993)$ provided additional illustrations of this specimen and calculated an estimated length of $2.6 \mathrm{~m}$ for the complete animal based on comparison with Platecarpus.

Long (1998) reported three associated trunk/caudal vertebrae (WAM 91.8.16) from the Miria Formation of Cardabia Station in the Giralia Ranges, south of Exmouth Gulf, centralwestern Western Australia. The specimens (Fig. 2E, F) were well preserved with complete neural arches present on two of the centra, and appear to represent a large (around $6-8 \mathrm{~m}$ ) mosasaurid of uncertain affinity. The Miria Formation has also

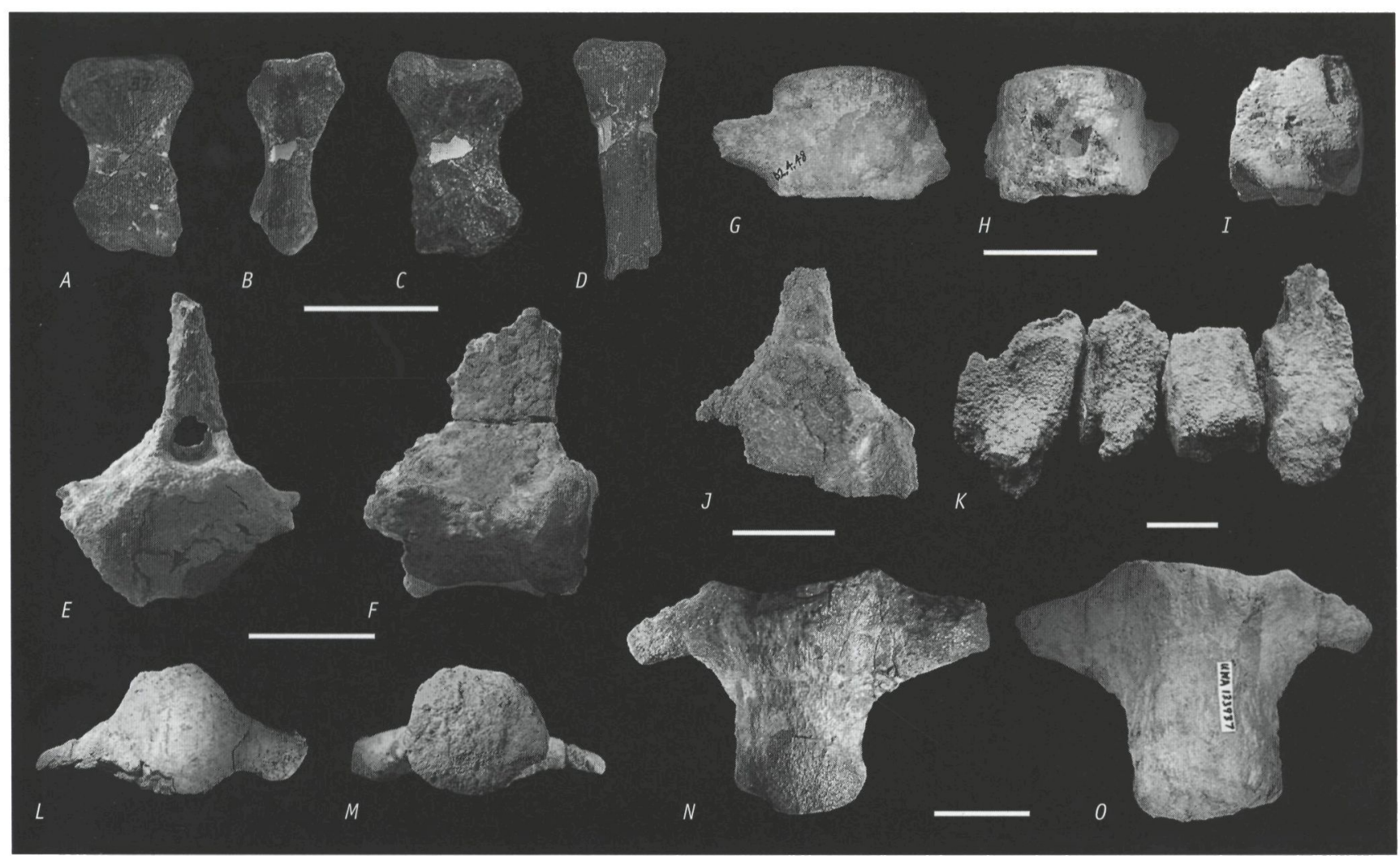

Fig. 2. Mosasaur remains from the Late Cretaceous deposits of Western Australia. cf. Platecarpus ulna (UWA 37092) in A - dorsal; B - posterior; and $C$ - ventral views; $D$ - cf. Platecarpus phalanx (UWA 37092) in dorsal view. Scale bar is $30 \mathrm{~mm}$. WAM 91.8.16-B, mosasaurid anterior caudal vertebra (Miria Formation) in E - anterior; and F-lateral views. Scale bar is $40 \mathrm{~mm}$. WAM 02.2.48, probable plioplatecarpine caudal vertebra (from Miria Formation locality south of West Tank, Giralia Station, Giralia Ranges) in G - ventral; $H$ - dorsal; and I - lateral views. Scale bar is $40 \mathrm{~mm}$. J - probable plioplatecarpine caudal vertebra (WAM 98.7.5, Molecap Greensand) in anterior view; $K$ - caudal series in lateral view. Scale bar is $40 \mathrm{~mm}$. Korojon Calcarenite mosasaurid ?pygal vertebra (UWA 133937) in L-anterior; $M$ - posterior; $N$ - ventral; and $O$ - dorsal views. Scale bar is $40 \mathrm{~mm}$. 
subsequently produced other fragmentary mosasaur vertebrae (Fig. 2G - I). These are all taxonomically indeterminate but suggest the presence of a small-bodied probable plioplatecarpine (identified on the basis of small size and rounded centra) in the deposit.

Recently, the Molecap Greensand has yielded additional mosasaur remains including a series of ten trunk/caudal vertebrae with articulating haemal arches (WAM 98.7.1-10) from a locality north of the township of Dandaragan, southwestern Western Australia (Long, 1999). This material (Fig. 2J, K) is currently under study by JEM and JAL, but appears to belong to a moderately sized plioplatecarpine.

In 2003, a field party from the University of Western Australia recovered an isolated mosasaur ?pygal vertebra (UWA 133937, Fig. 2L - 0) from deposits of the Korojon Calcarenite in the area of C-Y Creek, Giralia Ranges. This specimen has yet to be described, but nevertheless represents the first discovery of vertebrate remains from this unit, and also a new stratigraphic occurrence for Mosasauridae in Australia.

\section{Palaeobiogeographic implications of Australian mosasaurs}

As presently understood, the Australian mosasaur record is dominated by plioplatecarpines. Members of this group are known from marine strata in North America, Europe, North Africa, the Middle East and northern South America (e.g., Russell, 1967; Lingham-Soliar, 1991, 1994a - c; Mulder, 1999; Bardet et al., 2000; Bardet \& Pereda Suberbiola, 2002; Kiernan, 2002), indicating a wide distribution throughout the Northern Hemisphere. Remains attributed to the plioplatecarpine genus Platecarpus have also been reported from Upper Cretaceous (Campanian-Maastrichtian) deposits in the Southern Hemisphere, and in particular New Zealand (Lydekker, 1888; Welles \& Gregg, 1971; Lingham-Soliar, 1994b). Subsequent reassessment, however, indicates that the taxonomic assignment of this material is untenable (Welles \& Gregg, 1971; Bell et al., 1999). As a result, the recent definitive recognition of plioplatecarpines in Western Australia (Martin \& Long, 2002), in conjunction with other 'russellosaurine' taxa (Plioplatecarpus, Lakumasaurus, Tylosaurus, Taniwhasaurus and possibly Hainosaurus) in New Zealand (Welles \& Gregg, 1971; Bell et al., 1999) and Antarctica (Martin, 2002; Martin et al., 2002; Novas et al., 2002), is highly significant as it firmly re-establishes the presence of this lineage in the southern oceans by at least Coniacian times.

Mosasaurs achieved a near-global radiation during the Late Cretaceous. However, many taxa appear to have been regionally restricted, probably in response to localised controlling factors such as habitat preference, prey productivity and prevailing water temperatures. Evidence for this has been found in the well-documented mosasaur assemblages of North America, which show marked palaeoenvironmental (e.g., Kiernan, 2002) and latitudinally influenced (e.g., Nicholls \& Russell, 1990) taxonomic segregation. Interestingly, latitude in particular and its relationship to prevailing water temperature, is thought to have been a major constraint on the taxonomic composition of North American mosasaur faunas. For example, Russell (1966) and Nicholls \& Russell (1990) noted that plioplatecarpines, and specifically the genus Platecarpus, seem to have dominated Campanian high-latitude environments (e.g., Anderson River, Canadian North West Territories placed at $\sim 70^{\circ} \mathrm{N}$ ), in contrast to contemporaneous lower-latitude regions (e.g. Niobrara Formation, Kansas, Mooreville Chalk, Alabama, ranging from $\sim 30^{\circ}-40^{\circ} \mathrm{N}$ ), which exhibited a more partitioned fauna of plioplatecarpines, mosasaurines, tylosaurines and basal mosasaurids (Halisaurus). Interestingly, this distribution pattern is reversed in the Southern Hemisphere where Campanian-Maastrichtian high-latitude localities (e.g., New Zealand and Antarctica) support a taxonomically diverse assemblage of not only plioplatecarpines, but also tylosaurines and predominantly mosasaurines (Wiffen, 1990; Bell et al., 1999; Martin et al., 2002; Novas et al., 2002). The reasons for this contrasting distributional pattern are unknown, although clearly several mosasaurian clades appear to have successfully radiated into high-latitude cooler-water environments during the Late Cretaceous.

All of the currently documented high-latitude mosasaur localities in the Southern Hemisphere (namely Seymour and Vega Islands, Antarctica and North and South Islands, New Zealand) are thought to have lain at around $80^{\circ} \mathrm{S}$ throughout much of the mid-Late Cretaceous. Conversely, the Western Australian deposits occupied a lower-latitude region between $40^{\circ} \mathrm{S}$ (Carnarvon Basin) and $50^{\circ} \mathrm{S}$ (Perth Basin; Embleton, 1984). This is comparable to some of the lower latitude localities in North America (e.g. Niobrara Formation), as well as the southern mid-latitude deposits of northern Patagonia (which lay at $\sim 50^{\circ} \mathrm{S}$ ). In the latter, fragmentary mosasaurine remains occur within a Late Cretaceous (Campanian-Maastrichtian) Austral Transitional province (situated above $46^{\circ} \mathrm{S}$ ) characterised by marine reptile (plesiosaur), macroinvertebrate and microfossil assemblages exhibiting a mixture of Tethyan and Weddellian influences (see Gasparini et al., 2001 for discussion). Transitional assemblages also occur in the Upper Cretaceous of Western Australia (see below), perhaps suggesting that mosasaur faunas from this region might similarly have incorporated taxa from both low- and high-latitude areas.

\section{Correlations with sympatric vertebrate fossil records}

Direct correlation of the Western Australian mosasaur remains with those known from other transitional mid-latitude faunas is impossible given the fragmentary nature of the current material. Nevertheless, assessment of associated nonmosasaurian vertebrate fossils does provide a basis for 
preliminary palaeobiogeographic comparisons. To date, several important taxa have been identified (especially from the Molecap Greensand), mainly representing widely distributed non latitude-specific forms. Importantly however, some characteristic high-latitude taxa are present including potentially the elasmosaurid plesiosaur Mauisaurus (Long \& Cruickshank, 1998), a taxon known elsewhere from austral high-latitude localities in New Zealand (Welles \& Gregg, 1971; Wiffen \& Moisley, 1986), the Antarctic Peninsula (Fostowicz-Frelick \& Gażdzicki, 2001) and Patagonia (Gasparini et al., 2003). Examples of cosmopolitan vertebrates include the Cretaceous teleost Protosphyraena sp. (McNamara et al., 1993) and the widespread, long-ranging selachians Notorynchus, Squatina, Paraorthacodus and Cretalamna. These are common in the Molecap Greensand, together with other selachian taxa such as Centrophoroides, Protosqualus, Anomotodon and Protolamna, all of which have good records from the Cretaceous of Europe and North America (Cappetta, 1987; Williamson et al., 1993). Chimaeroid material from the Molecap Greensand has yet to be described but appears to be related to the cosmopolitan genera Ischyodus and Edaphodon (Kemp, 1991; McNamara et al., 1993).

Very few of the Molecap Greensand chondrichthyans have been diagnosed to species level. The only confidently identified taxa are the lamnids Cretalamna appendiculata, a well-known Cretaceous pelagic form with near-worldwide distribution (Cappetta, 1987; Williamson et al., 1993), Cretalamna gunsoni (M. Siverson, pers. comm. 2004), an endemic species known elsewhere from the upper Albian-Cenomanian Alinga Formation, Western Australia (Siverson, 1996); and Squalicorax kaupi, a cosmopolitan anacoracid (Cappetta, 1987; Siverson, 1996). This pattern, characterised by a minimum degree of endemism, is common to Cenomanian-Turonian selachian faunas from elsewhere in the world, which also tend to exhibit regionalised species-level differentiation, accounting for most of the geographic variation between what are otherwise remarkably homogeneous generic-level faunas (Williamson et al., 1993).

Chondrichthyan remains from the Miria Formation are poorly known, but may include the wide-ranging anacoracid Squalicorax. This taxon has a near-worldwide distribution throughout much of the Late Cretaceous, although the group does not persist past the end of the Mesozoic (Cappetta, 1987).

\section{Correlations with existing macroinvertebrate/ microfossil data}

The generally cosmopolitan palaeobiogeographic affinities of marine vertebrates found in the Western Australian mosasaurbearing units are coherent with those of the invertebrates and microfossils. For example, in the Molecap Greensand (and overlying Gingin Chalk), macroinvertebrates (primarily ammonites) have a pandemic character, sharing representatives with contemporary assemblages in northern Australia and New Zealand (Wright, 1963; Henderson, 1973). Similarly, micro- invertebrates, particularly foraminifera, exhibit a low degree of faunal endemism (a common phenomenon throughout the Late Cretaceous of Australia), and a distinctly transitional faunal composition including taxa from both austral cool water and northern Tethyan warm water regions (Henderson et al., 2000). Studies of calcareous nannofossils from the Perth and Carnarvon basins indicate a distinct austral influence prior to the early Campanian (Shafik, 1990). By the Maastrichtian, however, marked faunal segregation had occurred with the more northerly Carnarvon Basin forming part of an extratropical nannoprovince dominated by warmwater conditions and a cosmopolitan Tethyan-influenced fauna. In contrast, the southern Perth Basin comprised a distinct austral nannoprovince, characterised by cooler waters and an almost exclusively southern-influenced nannofossil assemblage. Support for this observation has been found in the sympatric macroinvertebrate record, which shows that benthic molluscs, especially in the Miria Formation (Carnarvon Basin), were highly cosmopolitan, reflecting the warmer-water conditions and close proximity of the austral margin of the Indian 0cean to the Tethyan Realm (Darragh \& Kendrick, 1994). Ammonites also are represented by a mixed fauna that includes some distinctive austral elements (e.g., kossmaticeratids) but is otherwise dominated by cosmopolitan immigrant taxa probably derived from contemporary assemblages in southeastern Africa, and particularly southern India (Henderson \& Heron, 1977; Henderson \& McNamara, 1985b; Henderson et al., 1992, 2000).

\section{Conclusions}

Australian mosasaur fossils are very poorly known but nevertheless provide an interesting addition to the group's global record. The fragmentary nature of the material hampers their utility for definitive palaeobiogeographic comparisons. However, when placed in context with other associated fossils some preliminary hypotheses can be put forward. For example, the Western Australian mosasaur fauna (presently comprising mainly plioplatecarpines and perhaps the genus Platecarpus) may well have been cosmopolitan in composition (similar to other well-documented austral mosasaur assemblages; see Novas et al., 2002), with generic-level representatives from both northern Tethyan and austral high-latitude regions. This conclusion is supported by the pandemic character of sympatric vertebrate taxa (particularly chondrichthyans) and the transitional nature of macroinvertebrate/microfossil assemblages, which show marked regional differentiation between the Carnarvon and Perth Basin units. This to a large part reflects the recognised palaeobiogeographic separation of the northern and southern Indian 0ceans during the midCampanian (see Huber \& Watkins, 1992), and the subsequent development of distinct northern tropical and southern cool-water marine faunal provinces in the Australian region (Shafik, 1990). 


\section{Acknowledgements}

We thank Tim Flannery and Mike Lee (South Australian Museum) for their continuous support and enthusiasm for the study of Australian Cretaceous faunas, floras and environments. Mikael Siverson (Western Australian Museum) provided helpful information on the Late Cretaceous shark fauna of Western Australia. This manuscript benefited from the comments of Michael Caldwell and a second anonymous reviewer. The Australian Research Council (LP0453550 to BPK and M.Y.S. Lee: University of Adelaide), the South Australian Museum, Origin Energy, The Advertiser, The Waterhouse Club, the Coober Pedy Tourism Association, Commercial and General Capital Ltd and Kenneth J. Herman Inc. gave financial assistance for this research.

\section{References}

Apthorpe, M.C., 1979. Depositional history of the Upper Cretaceous of the Northwest Shelf, based on Foraminifera. APEA Journal 19: 74-89.

Bardet, N., Cappetta, H., Pereda Suberbiola, X., Mouty, M., Al Maleh, A.K., Ahmad, A.M., Khrata, O. \& Gannoum, N., 2000. The marine vertebrate faunas from the Late Cretaceous phosphates of Syria. Geological Magazine 137: $269-290$

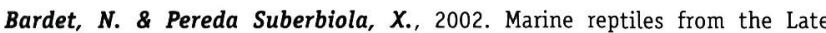
Cretaceous phosphates of Jordan: palaeobiogeographical implications. Geodiversitas 24: 831-839.

Belford, D.J., 1958. Stratigraphy and micropalaeontology of the Cretaceous of Western Australia. Geologische Rundschau 47: 629-647.

Bell, G.L., 1997. A phylogenetic revision of North American and Adriatic Mosasauroidea. In: Callaway, J.M. \& Nicholls, E.L. (eds): Ancient marine reptiles. Academic Press, San Diego: 293-332.

Bell, G.L., Caldwell, M.W., Holmes, R., Wiffen, J. \& McKee, J., 1999. Sea monsters of the South Pacific: on the Late Cretaceous mosasaurs from New Zealand. Journal of Vertebrate Paleontology 19 (Suppl. to 3): 37A.

Cappetta, H., 1987. Chondrichthyes II: Mesozoic and Cenozoic Elasmobranchii. Handbook of Paleoichthyology Volume 3B. Gustav Fischer Verlag, Stuttgart: $193 \mathrm{pp}$

Darragh, T.A. \& Kendrick, G.W., 1991. Maastrichtian Bivalvia (excluding Inoceramidae) from the Miria Formation, Carnarvon Basin, northwestern Australia. Records of the Western Australian Museum, Supplement 36: 1-102.

Darragh, T.A. \& Kendrick, G.W., 1994. Maastrichtian Scaphopoda and Gastropoda from the Miria Formation, Carnarvon Basin, northwestern Australia. Records of the Western Australian Museum, Supplement 48: 1-76.

Edgell, H.S., 1957. The genus Globotruncana. Micropaleontology 3: 101-122.

Embleton, B.J.J., 1984. Australia's global setting: past global settings. In: Veevers, J. J. (ed.), Phanerozoic Earth History of Australia. Clarendon Press, Oxford: 11-17.

Etheridge, $\boldsymbol{R} ., 1913$. The Cretaceous fossils of the Gingin Chalk. Bulletin of the Geological Survey of Western Australia 55: 9-31.

Feldtmann, F.R., 1951. Pectens of the Gingin Chalk 3. Journal of the Royal Society of Western Australia 5: 9-39.
Feldtmann, F.R., 1963. Some pelecypods from the Cretaceous Gingin Chalk, western Australia, together with descriptions of the principal chalk exposures. Journal of the Royal Society of Western Australia 46: 101-125.

Fostowicz-Frelik, L. \& Gażdzicki, A., 2001. Anatomy and histology of plesiosaur bones from the Late Cretaceous of Seymour Island, Antarctic Peninsula. In: Gażdzicki, A. (ed.): Palaeontological results of the Polish Antarctic expeditions. Part III, Palaeontologia Polonica 60: 7-32.

Gasparini, Z., Casadio, S., Fernandez, M. \& Salgado, L., 2001. Marine reptiles from the Late Cretaceous of northern Patagonia. Journal of South American Earth Sciences 14: 51-60.

Gasparini, Z., Salgado, L. \& Casadio, S., 2003. Maastrichtian plesiosaurs from northern Patagonia. Cretaceous Research 24: 157-170.

Glenister, B.F., Miller, A.K. \& Furnish, W.M., 1956. Upper Cretaceous and Early Tertiary nautiloids from Western Australia. Journal of Paleontology 30: 492-503.

Henderson, R.A., 1973. Clarence and Raukumara Series (Albian-?Santonian) Ammonoidea from New Zealand. Transactions of the Royal Society of New Zealand 3: 71-123.

Henderson, R.A. \& Heron, M.L., 1977. A probabilistic method of palaeobiogeographic analysis. Lethaia 10: 1-15.

Henderson, R.A., Kennedy, W.J. \& McNamara, K.J., 1992. Maastrichtian heteromorph ammonites from the Carnarvon Basin, Western Australia. Alcheringa 16: 133-170.

Henderson, R.A. \& McNamara, K.J., 1985a. Taphonomy and ichnology of cephalopod shells in a Maastrichtian chalk from Western Australia. Lethaia 18: $305-322$.

Henderson, R.A. \& McNamara, K.J., 1985b. Maastrichtian non-heteromorph ammonites from the Miria Formation, Western Australia. Palaeontology 28: 35-88.

Henderson, R.A., Crampton, J.S., Dettmann, M.E. Douglas, J.G., Haig, D., Shafik, S., Stilwell, J. D. \& Thulborn, R.A., 2000. Biogeographical observations on the Cretaceous biota of Australasia. Memoirs of the Australasian Association of Palaeontologists 23: 355-404.

Hocking, R.M., Moors, H.T. \& Van de Graff, W.J.E., 1987. Geology of the Carnarvon Basin. Geological Survey of Western Australia, Bulletin 133: 1-289.

Huber, B.T. \& Watkins, D.K., 1992. Biogeography of Campanian-Maastrichtian calcareous plankton in the region of the Southern 0cean: paleogeographic and paleoclimatic implications. American Geophysical Union, Antarctic Research Series 56: 31-60.

Kear, B.P., 2003. Cretaceous marine reptiles of Australia: a review of taxonomy and distribution. Cretaceous Research 24: 277-303.

Kear, B.P., 2004. Biogeographic and biostratigraphic implications of Australian Mesozoic marine reptiles. Australian Biologist 17: 4-22.

Kemp, N., 1991. Chondrichthyans in the Cretaceous and Tertiary of Australia. In: Vickers-Rich, P., Monaghan, J. M., Baird, R. F. \& Rich, T. H. (eds): Vertebrate Palaeontology of Australasia. Pioneer Design Studio, Monash University, Melbourne: 497-568. 
Kiernan, C.R., 2002. Stratigraphic distribution and habitat segregation of mosasaurs in the Upper Cretaceous of western and central Alabama, with an historical review of Alabama mosasaur discoveries. Journal of Vertebrate Paleontology 22: 91-103.

Lingham-Soliar, T., 1991. Mosasaurs from the Upper Cretaceous of Niger. Palaeontology 34: 653-670.

Lingham-Soliar, T., 1994a. First record of mosasaurs from the Maastrichtian (Upper Cretaceous) of Zaire. Paläontologische Zeitschrift 68: 259-265.

Lingham-Soliar, T., 1994b. The mosasaur 'Angolasaurus' bocagei (Reptilia: Mosasauridae) from the Turonian of Angola re-interpreted as the earliest member of the genus Platecarpus. Paläontologische Zeitschrift 68: 267-282.

Lingham-Soliar, T., 1994c. The mosasaur Plioplatecarpus (Reptilia: Mosasauridae) from the Upper Cretaceous of Europe. Bulletin de l'Institut Royal des Sciences Naturelles de Belgique, Sciences de la Terre 64: 177-221.

Long, J.A., 1990. Dinosaurs of Australia and other animals of the Mesozoic Era, Reed Books, Balgowlah, NSW: $87 \mathrm{pp}$.

Long, J.A., 1993. Dinosaurs of Australia and other animals of the Triassic, Jurassic and Cretaceous Periods. Reed Books, Balgowlah, NSW: 88 pp.

Long, J.A., 1998. Dinosaurs of Australia and New Zealand and other animals of the Mesozoic Era. University of New South Wales Press, Sydney: 188 pp.

Long, J.A., 1999. Prehistoric sea monsters of the west. Nature Australia 26: 46-53.

Long, J.A. \& Cruickshank, A.R.I., 1998. Further records of plesiosaurian reptiles of Jurassic and Cretaceous age from Western Australia. Records of the Western Australian Museum 19: 47-55.

Lundelius, E. \& Warne, S.St.J., 1960. Mosasaur remains from the Upper Cretaceous of Western Australia. Journal of Paleontology 34: 1215-1217.

Lydekker, R., 1888. Catalogue of the Fossil Reptilia and Amphibia in the British Museum (Natural History). Part I, British Museum, London: 309 pp.

Martin, J.E., 2002. Late Cretaceous Antarctic vertebrate fossils in the British Antarctic Survey collections, Cambridge, England. Journal of Vertebrate Paleontology, 22 (Supplement to 3): 83A.

Martin, J., Bell, G., Case, J., Chaney, D., Fernández, M., Gasparini, Z., Reguero, M. \& Woodburne, M., 2002. Mosasaurs (Reptilia) from the Late Cretaceous of the Antarctic Peninsula. In: Gamble, J.A, Skinner, D.N.B. \& Henrys, S. (eds.): Antarctica at the close of a millenium: 8th International Symposium of Antarctic Earth Sciences. Royal Society of New Zealand Bulletin 35: 293-299.

Martin, J.E. \& Long, J.A., 2002. Implications of the mosasaurs (Reptilia: Squamata) from the Late Cretaceous of Australia. International Palaeontological Congress, Sydney, Australia, Geological Society of Australia, Abstracts 68: 238.

McNamara, K.H., Friend, D. \& Long, J., 1993. A Guide to fossils of the Gingin Chalk. Western Australian Museum, Perth: 55 pp.

McNamara, K.H., Rexilius, J.P., Marshall, N.G. \& Henderson, R.A., 1988. The first record of a Maastrichtian ammonite from the Perth Basin, Western Australia, and its biostratigraphical significance. Alcheringa 12: 163-168.

McWae, J.R.H., Playford, P.E., Lindner, A.W., Glenister, B.F. \& Balme, B.E., 1958. The stratigraphy of Western Australia. Journal of the Geological Society of Australia 4: 1-161.

Molnar, R.E., 1991. Fossil reptiles in Australia. In: Vickers-Rich, P., Monaghan, J.M., Baird, R.F. \& Rich, T.H. (eds), Vertebrate Palaeontology of Australasia. Pioneer Design Studio, Monash University, Melbourne: 605-702.
Mulder, E.W.A., 1999. Transatlantic latest Cretaceous mosasaurs (Reptilia: Lacertilia) from the Maastrichtian type area and New Jersey. Netherlands Journal of Geosciences 78: 281-300.

Nicholls, E.L. \& Russell, A.P., 1990. Paleobiogeography of the Cretaceous Western Interior Seaway of North America: the vertebrate evidence. Palaeogeography, Palaeoclimatology, Palaeoecology 79: 149-169.

Novas, F.E., Fernández, M., Gasparini, Z. B., Liro, J.M., Nuñez, H.J. \&

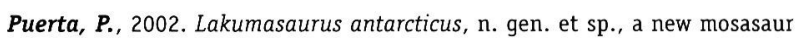
(Reptilia: Squamata) from the Upper Cretaceous of Antarctica. Ameghiniana 39: 245-249.

Playford, P.E., Cockbain, A.E., Low, G.H., 1976. Geology of the Perth Basin. Geological Survey of Western Australia Bulletin 124: 1-311.

Russell, D.A., 1966. Cretaceous vertebrates from the Anderson River N.W.T. Canadian Journal of Earth Sciences 4: 21-38.

Russell, D.A., 1967. Systematics and morphology of American mosasaurs (Reptilia: Sauria). Bulletin of the Peabody Museum of Natural History, Yale University 23: 1-240.

Shafik, S., 1990. Late Cretaceous nannofossil biostratigraphy and biogeography of the Australian western margin. Bureau of Mineral Resources, Geology and Geophysics, Report 295: 1-164.

Siverson, M., 1996. Lamniform sharks of the Mid-Cretaceous Alinga Formation and Beedagong Claystone, Western Australia. Palaeontology 39: 813-849.

Welles, S.P. \& Gregg, D.R., 1971. Late Cretaceous marine reptiles of New Zealand. Records of the Canterbury Museum 9: 1-111.

Wiffen, J., 1990. New mosasaurs (Reptilia: Family Mosasauridae) from the Upper Cretaceous of North Island, New Zealand. New Zealand Journal of Geology and Geophysics 33: 67-85.

Wiffen, J. \& Moisley, W.L., 1986. Late Cretaceous reptiles (families Elasmosauridae and Pliosauridae) from the Mangahouanga Stream, North Island, New Zealand. New Zealand Journal of Geology and Geophysics 29: 205-252.

Williamson, T.E., Kirkland, J.I. \& Lucas, S.G., 1993. Selachians from the Greenhorn Cyclotherm ('middle' Cretaceous: Cenomanian-Turonian), Black Mesa, Arizona, and the paleogeographic distribution of Late Cretaceous selachians. Journal of Paleontology 67: 447-474.

Wright, C.W., 1963. Cretaceous ammonites from Bathurst Island, northern Australia. Palaeontology 6: 597-614. 